8. W ru.wikipedia.org> Лидогенерация

9. Ван Дейк Т.А. Язык. Познание. Коммуникация./ Т.А. Ван Дейк.- М.: Про-гресс, 1989.-310 с.

10. Фадеева, М.Ю. Learn English politeness in communication: учебное пособие / М.Ю. Фадеева. - Орск: Издательство Орского гуманитарно-технологического института (филиала) ОГУ, 2011. - 107 с. ISBN 978-5-8424-0569-5.

11. Фадеева, М.Ю. Формирование лингвокоммуникативной культуры общения в бизнесе: учебное пособие / М.Ю. Фадеева. - Орск: Издательство ОГТИ (филиала) ОГУ, 2014. - 94 с. - ISBN 978-58424-0721-7.

12. Фадеева, М Ю. Методологические аспекты высшего образования при обучении иностранному языку в сфере экономики и менеджмента: учебно-методическое пособие / М.Ю. Фадеева. - Орск: Издательство Орского гуманитарно-технологического института (филиала) ОГУ, 2016. - 109 с. ISBN 978-5-8424-0822-1.

13. Фадеева, М.Ю. Развитие профессиональной компетентности студентов в сфере инфобизнеса и инфокоммуникаций: учебно-методическое пособие / М.Ю. Фадеева. - Орск: Издательство Орского гуманитарно-технологического института (филиала) ОГУ, 2017. - 124 с. - ISBN 978-5-8424-08573.

\title{
Чжоу Елинь \\ О некоторых традиционных и новых методах и технологиях в онлайн-обучении игре на фортепиано в России и КНР
}

\author{
РГПУ им А И Гериена \\ (Россия, Санкт-Петербург)
}

doi: $10.18411 / \mathrm{sr}-10-08-2021-31$

\section{Аннотация}

В наши дни назрела необходимость обобщения и применения существующего практического опыта онлайн-обучения. Ряд новых методов и технологий позволяют компенсировать невозможность применения традиционных методов и приёмов фортепианной педагогики. В статье приведены некоторые наблюдения и наработки российских и китайских преподавателей по применению различных вариантов видеометода и использованию дисклавиров (гибридных фортепиано).

Ключевые слова: традиции российской фортепианной педагогики, онлайнобучение фортепиано, видеометод, видеозапись с комментариями, дисклавир.

В связи с длительной ситуацией глобальной пандемии и неопределёнными прогнозами на будущее несомненна актуальность освоения опыта онлайн-обучения игре на фортепиано. Удалённое обучение следует принимать как факт современной жизни. Методы и технологии онлайн-работы - то, чем необходимо овладеть каждому практикующему или будущему педагогу - студенту музыкального или музыкальнопедагогического вуза.

Фортепианное обучение, как известно, носит практико-ориентированный характер. В нём соединяются искусство и ремесло, которые передаются непосредственно от педагога к ученикам, «из рук в руки». Согласно традициям российской фортепианной школы, значительную роль в обучении играют: тактильный контакт рук педагога и ученика; включение в работу осязания (показ педагогом приёма звукоизвлечения непосредственно на руке ученика); прямое воздействие на тело ученика (чуть приподнять локти, надавить на поднятые плечи, проверить свободу мышц кисти и запястья и многое другое). В классе педагог напрямую контролирует качество звукоизвлечения и мышечный тонус ученика, которые тесно взаимосвязаны. Профессор Российской Академии музыки им. Гнесиных так вспоминает занятия у своего известнейшего педагога - А.Д. Артоболевской (1905 - 1988): «Всё происходит через активный контакт, что чрезвычайно важно. Только через собственные ощущения можно быстро и эффективно исправить любые зажатости в игровом аппарате. (...) Только так ученик сможет понять степень интенсивности, глубины, осторожности, с 
которыми необходимо прикасаться к клавишам кончиками пальцев. И едва ли не самое важное - гибкость и мягкость, с какими надо передавать нажатие одной клавиши нажатию другой» [1, с. 68].

Говоря о том, какие черты отличают российскую фортепианную школу, замечательная пианистка и педагог Т. П. Николаева $(1924-1993)$ называет главное «...отношение к звуку, певучий “тон”, мелодичность исполнения, желание как можно глубже постичь содержание исполняемого произведения» [2, с. 157]. Культура звука передаётся через показ, передачу ощущений, образные сравнения. Из воспоминаний профессора С. Л. Доренского о своём учителе, легендарном А. Б. Гольденвейзере (1875 - 1961): «Как он показывал в классе разучиваемые произведения, как рассказывал о них! Рядом с ним нельзя было не влюбиться в пианизм, в звуковую палитру рояля, в обольстительные таинства фортепианной техники» [8, с. 209]. Всё вышеперечисленное является «сердцевиной» российской фортепианной педагогики.

Казалось бы, онлайн-режим полностью лишает педагогов-пианистов всех перечисленных возможностей, снижает уровень обучения. В этой связи необходимо понять, как дистанционные технологии могут компенсировать невозможность применения ряда традиционных методов и приёмов обучения игре на фортепиано.

Значительный опыт в онлайн-обучении исполнителей сложился к настоящему времени в КНР. На музыкальных факультетах институтов, в специальных музыкальных школах используются инновационные технологические решения. С 2019 г. в КНР работают экспериментальные классы, в которых исследуются условия эффективности онлайн-образования. Обучение в классе фортепиано в школе «Бейху» (город Чаньчун) курируют педагоги из Академического музыкального училища при Московской государственной консерватории им. П. И. Чайковского. Для обучения пианистов на протяжении двух лет используются видео, музыкальные программы, специальные приложения, а также гибридные пианино («дисклавиры», «умные пианино») [3, с. 100]. В России онлайн-обучение, ранее развивавшееся лишь единичными преподавателями, с началом пандемии сразу стало массовой практикой. И здесь тоже получен ряд ценных наблюдений и выводов.

Практика показала, что видеометод одним из наиболее востребованных педагогами стал видеометод. Действительно, он похож на полное прослушивание произведения в начале обычного (не дистанционного) урока. Известные российские педагоги прошлого (А. Б. Гольденвейзер, Г. Г. Нейгауз, Б. М. Берлин) и настоящего (В. В. Пясецкий, М. А. Марченко и др.) указывают, что важно слушать произведение полностью, не останавливая ученика. Это позволяет и ученику «собрать» свой замысел, и педагогу лучше распознать недостатки и более отчётливо сформулировать наиболее важные рекомендации [5].

В современной онлайн-практике видеометод используется в различных вариантах:

1. С одновременной обратной связью, когда видеопоток идёт одновременно и от ученика, и от педагога.

2. С разновременной обратной связью. В этом случае ученик присылает видеозапись (программы, произведения, фрагментов произведений) педагог просматривает и даёт обратный отклик и рекомендации. Рекомендации и показ педагога в письменной, видео- или аудио-форме пересылаются ученику.

Преимущество видеометода с разновременной обратной связью весьма значительны. По отзывам опрошенных педагогов: 
- ученики намного больше занимаются в процессе подготовки и записи видео;

- метод (просто записать себя на камеру телефона) прост, не требует специального дорогостоящего оборудования, с ним все легко справляются;

- и педагог, и ученик имеют возможность неоднократно прослушивать записи и рекомендации, возвращаться к ним, сравнивать старые и новые видео.

Как отмечают педагоги, ценно то, что маленькая видеокамера телефона позволяет показать различные ракурсы исполнения («подлезть под каждый пальчик»). Были найдены удобные варианты размещения камеры (сотового телефона) во время записи видео (Рис. 1). Во время прослушивания лучше пользоваться наушниками. Младшим школьникам помощь оказывают родители (снимают, держат камеру, делают пометки в нотах). Более взрослые ученики делают всё самостоятельно.
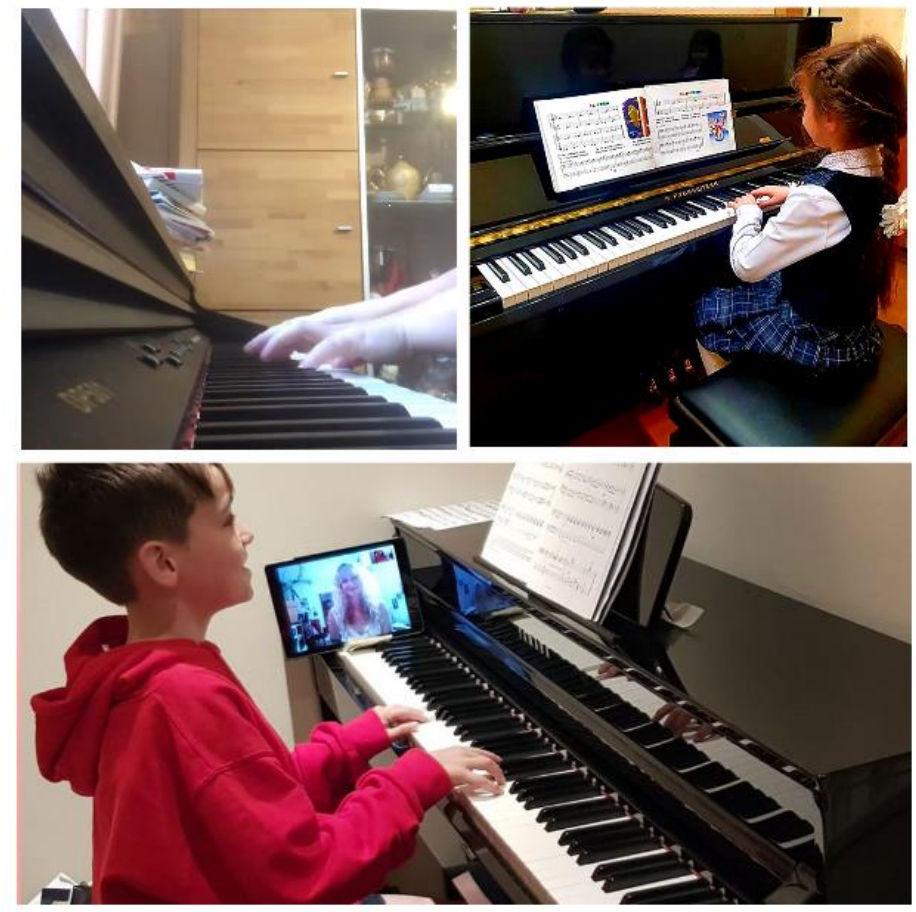

Рис. 1. Ученики записывают видео с игрой произведений [фотографии предоставлень преподавателями музыкальных школ, 2021 г.]

Преимущество данного метода подтверждается на самом высоком уровне профессионального образования. Известная пианистка и авторитетный педагог Московской государственной консерватории Е. В. Мечетина называет видеозапись с комментариями наиболее информативным методом с точки зрения качества записи и воспроизведения звука. Результаты этого метода наиболее высоки. Недостатком является лишь значительная времязатратность метода [6].

Гибридные фортепиано (дисклавиры) были спроектированы компанией «Ямаха» почти три десятилетия назад, и по работе с ними накоплен достаточно большой опыт. Это акустическое фортепиано, но с включением электроники, которая позволяет записывать и воспроизводить все перемещения подвижных частей инструмента. Дисклавиры имеют возможность удалённого подключения на любом расстоянии. Передача звука от педагога к ученику происходит почти без искажений и без лишних датчиков и проводов [7]. Дисклавиры с успехом применяются на онлайн-уроках, онлайн-концертах, мастер-классах, экзаменах (Рис. 2). 


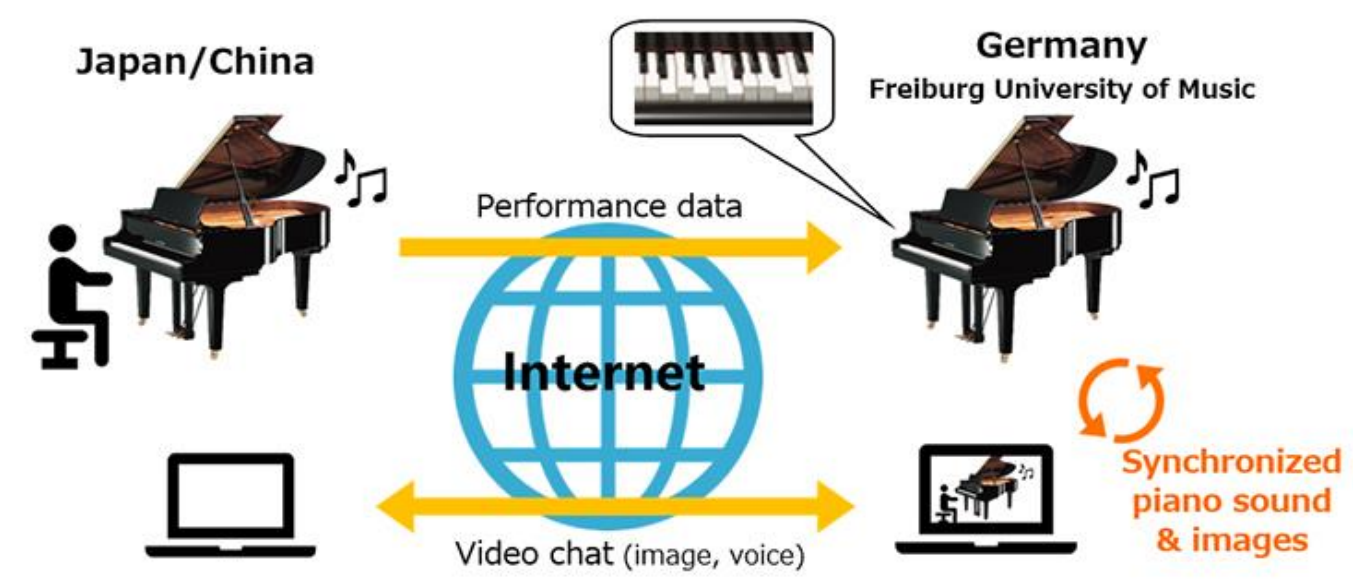

Рис. 2. Схема проведения вступительных экзаменов летом 2021 г. во Фрайбургском университете музыки с помощьюю системы «Дисклавир» [7]

Применение дисклавиров активизирует самостоятельную работу учащихся, способствует развитию слуховой внимательности, навыков анализа своего исполнения, самостоятельному творческому исследованию фортепианных интерпретаций [4, с. 166]. Но этот метод имеет и ограничение ввиду значительной стоимости самого инструмента и оборудования.

Таким образом, онлайн-обучение является выходом из «зоны комфорта» - и для учеников, и для педагогов (для последних в большей степени). Казалось бы, онлайнобучение противоречит ключевым установкам российской фортепианной педагогики. Но потери в качестве обучения можно компенсировать, гибко используя возможности различных инновационных технологий. Современный педагог должен, опираясь на лучшие традиции фортепианной педагогики, осваивать инновационные технологии и методы.

$$
* * *
$$

1. Богданов, Ю. А. Деятельность Анны Даниловны Артоболевской в контексте отечественной музыкальной педагогики и традиций русской фортепианной школы / Ю. А. Богданов // Ученые записки Российской академии музыки им. Гнесиных. - 2017. - № 2 (21). - С. 62-73.

2. Курганская, О. А. Александр Борисович Гольденвейзер. Мастер-класс / О. А. Курганская // Наука. Искусство. Культура. - 2016. - № 4 (12). - С. 151-159.

3. Лю, Ф. Фортепианная педагогика в современном Китае: процесс становления, особенности, проблемы / Ф. Лю // Актуальные проблемы высшего музыкального образования. - 2020. - № 2 (56). - C. 100-105.

4. Малыхина, И. В. Зарубежный опыт применения инновационных технологий в классе фортепиано / И. В. Малыхина // Мир науки, культуры, образования. - 2018. - № 6 (73). - С. 165-167.

5. Мастер-класс М. А. Марченко (ЦМШ при МГК). Февраль 2019 г. [Электронный ресурс]. - URL: https://www.youtube.com/watch?v=ME_Xs4Y1_ng (дата обращения: 01.06.2021).

6. Мечетина, Е. В. Дистанционное обучение в классе специального фортепиано : интервью / Е. В. Мечетина // ClassicalMusicNews.ru : электрон. СМИ о музыке [Электронный ресурс]. - URL: https://www.classicalmusicnews.ru/articles/distancionnoe-obuchenie-mechetina/ (дата обращения: 20.05.2021).

7. Новости образовательной сети Disklavier (The Disklavier Education Network) // Официальный сайт компании Yamaha. - [Электронный pecypc]. - URL: http://yamahaden.com/ (дата обращения: 01.06.2021).

8. Ц Цыпин, Г. М. Портреты советских пианистов : музыкально-критические статьи / Г. М. Цыпин. - 2е изд. - М. : Юрайт, 2020. -229 с. 